1.9 (f)

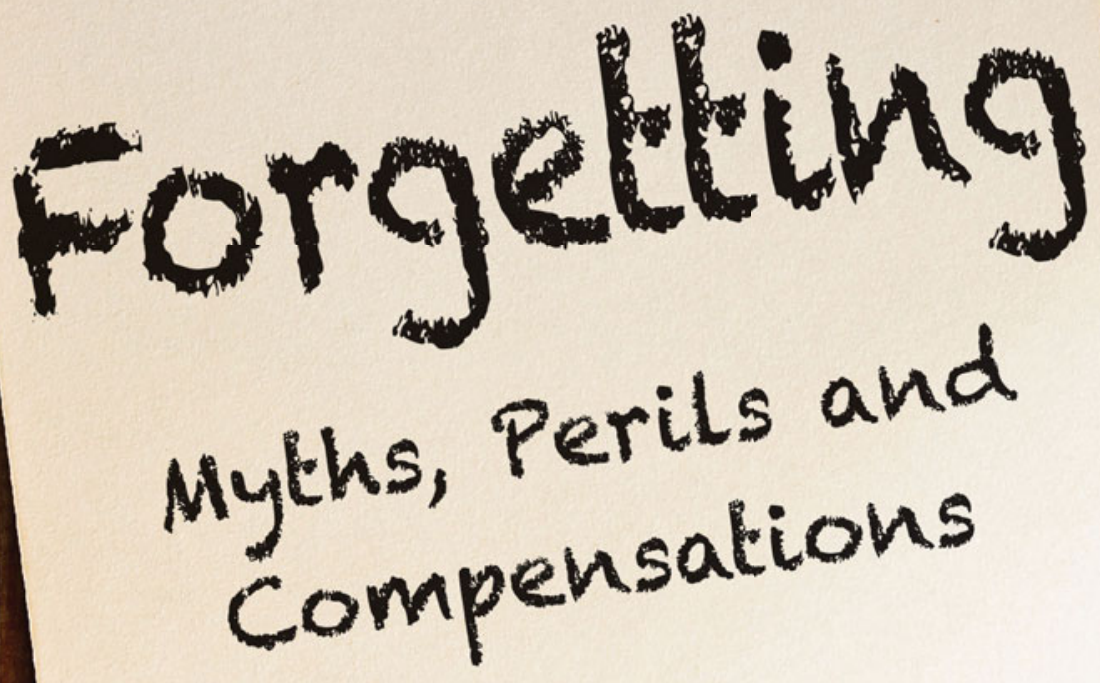

\title{
DOUWE DRAAISMA
}

Translated by Liz Waters 
FORGETTING 


\section{FORGETTING}

MYTHS, PERILS AND COMPENSATIONS

\section{DOUWE DRAAISMA}

Translated by Liz Waters

YALE UNIVERSITY PRESS

NEW HAVEN AND LONDON 
Published with the support of the Dutch Foundation for Literature.

English translation copyright (C) 2015 Liz Waters

Originally published in Dutch by Historische Uitgeverij as Vergeetboek (C) 2010 Douwe Draaisma

All rights reserved. This book may not be reproduced in whole or in part, in any form (beyond that copying permitted by Sections 107 and 108 of the U.S. Copyright Law and except by reviewers for the public press) without written permission from the publishers.

For information about this and other Yale University Press publications, please contact:

U.S. Office: sales.press@yale.edu www.yalebooks.com

Europe Office: sales@yaleup.co.uk www.yalebooks.co.uk

Typeset in Arno Pro by IDSUK (DataConnection) Ltd

Printed in Great Britain by TJ International Ltd, Padstow, Cornwall

Library of Congress Cataloging-in-Publication Data

Draaisma, D.

Forgetting : myths, perils and compensations / Douwe Draaisma. pages $\mathrm{cm}$

Includes bibliographical references and index.

ISBN 978-0-300-20728-6 (hardback)

1. Memory. 2. Recollection (Psychology). 3. Cognitive psychology. I. Title. BF371.D68124 2015

153.1'25-dc23

A catalogue record for this book is available from the British Library.

10987654321

iv 